\title{
Violence against women in South Africa: constitutional responses and opportunities
}

Beth Goldblatt*

A slightly amended version of this chapter appears in Dixon, R. \& Roux, T. (eds), Constitutional Triumphs, Constitutional Disappointments A Critical Assessment of the 1996 South African Constitution's Local and International Influence, (2018) Cambridge University Press, Cambridge, UK, pp. 141-173.

\section{Introduction}

Violence against women, present in every society in the world, is deeply embedded in South Africa's past and is a central feature of the post-democratic society. The South African Constitution is path-breaking in acknowledging this reality by providing a right to be free from violence in public and private realms. Over the past two decades since democracy, advocacy groups have been successful in lobbying and working with government to secure new legislation in the areas of domestic violence and rape. Implementation of these laws has, however, been mixed or poor and recourse to the law is limited for many, if not most, victims of this violence. A number of significant decisions have emerged from the Constitutional Court in relation to these laws and regarding aspects of the common law relevant to violence against women. This chapter surveys the jurisprudence on violence against women in assessing the Court's record in this area. While finding these decisions valuable in advancing the constitutional framework, the chapter suggests that fuller interpretation of the Constitution and more creative litigation and jurisprudence is necessary in contributing to the removal of the scourge of violence against South Africa's women.

Violence against women in South Africa is embedded in a history of brutality that has been central to the making of the country. ${ }^{1}$ Many of the acts of colonial dispossession, invasion, war, slavery and apartheid, as well as resistance to end this domination, have entailed

\footnotetext{
* Associate Professor, Faculty of Law, University of Technology Sydney; Visiting Fellow, Australian Human Rights Centre, Faculty of Law, University of New South Wales; Honorary Senior Research Fellow, School of Law, University of the Witwatersrand. I wish to thank the following people for their insightful observations in discussions on the topic of this chapter in February 2016: Cathi Albertyn, Elsje Bonthuys, Lisa Vetten, Rashida Manjoo and Bonita Meyersfeld.

${ }^{1}$ Patriarchy, race and class have been intimately connected in shaping the oppressive forms in which gender relations have played out in this country. For the classic article that developed this argument, see B. Bozzolli 'Marxism, feminism and South African studies' (1983) 9(2) Journal of Southern African Studies 139-171.
} 
violence to the bodies of women. ${ }^{2}$ While most of the historical articulations of the wars against black South Africans are behind us, the war against women and girls lives on in the everyday occurrence of domestic violence, femicide, rape, sexual abuse, harassment and harmful cultural practices such as ukuthwala (abduction of girls for marriage) ${ }^{3}$ and attacks on people labelled witches. ${ }^{4}$ Reported rape numbers in South Africa were the highest in the world in $2001 .^{5}$ Recent figures showed 43,195 cases of rape for the year 2014/15 although service providers estimate that as little as one in 13 rapes are reported. ${ }^{6}$ Rape takes a particularly brutal form in South Africa with a high rate of rape homicide and multiple perpetrator rape being very common. ${ }^{7}$ In a recent Constitutional Court decision Khampepe J noted that: ${ }^{8}$

Rape is perhaps the most horrific and dehumanising violation that a person can live through and is a crime that not only violates the mind and body of a complainant, but also one that vexes the soul. This crime is an inescapable and seemingly ever-present reality and scourge on the nation and the collective conscience of the people of South Africa.

The levels of female homicide as a whole are extremely high and domestic violence, though not adequately captured in official statistics, is epidemic. ${ }^{9}$ South Africa has the dubious honour of being known as the 'rape capital of the world'; as having a deputy president (now president) stand trial for rape of the daughter of his friend; ${ }^{10}$ as having sporting hero Oscar Pistorius convicted of murdering his partner; and as the place where so called 'corrective rape' of lesbians occurs. ${ }^{11}$ Many other high-profile cases are reported of horrific abuse of women and girls. While violence against women is a global problem it has a local character

\footnotetext{
${ }^{2}$ For a discussion of the history of rape and its various forms in South Africa, see Pumla Dineo Gqola, Rape - A South African Nightmare (Johannesburg: MFBooks, 2015).

${ }^{3}$ South African Law Reform Commission, 'The practice of Ukuthwala' (Revised Discussion Paper 138, Project 138, 2015).

${ }^{4}$ Both women and men are targeted: South African Law Reform Commission 'The review of The Witchcraft Suppression Act 3 of 1957' (Discussion Paper 139, Project 135, 2014) (Review of Witchcraft legislation). ${ }^{5}$ D. Smythe, Rape Unresolved: Policing Sexual Offences in South Africa (Cape Town: University of Cape Town Press, 2015).

${ }^{6}$ AfricaCheck , Factsheet: South Africa's 2014/15 assault and sexual crime statistics (2016) (available at https://africacheck.org/factsheets/factsheet-south-africas-201415-assault-and-sexual-crimestatistics/\#sthash.zuK16lgd.dpufhttps://africacheck.org/factsheets/factsheet-south-africas-201415-assault-andsexual-crime-statistics/).

${ }^{7}$ Smythe, Rape Unresolved (n. 5) at p. 17.

${ }^{8}$ Ndlovu $v$ The State [2017] ZACC 19, at 53.

${ }^{9}$ L. Vetten, 'Deserving and undeserving women: a case study of South African policy and legislation addressing domestic violence' MA thesis, University of the Witwatersrand (2013) p. 5.

${ }^{10}$ Although Jacob Zuma was acquitted of rape, his views and behaviour, as they emerged from the trial, represented a troubling understanding of sex and power in a leader of the country. For a discussion of the politics of the Zuma trial see, S. Hassim, 'Democracy's shadows: sexual rights and gender politics in the rape trial of Jacob Zuma' (2009) 68(1) African Studies 57-77.

${ }^{11}$ L. Mwambene and M. Wheal, 'Realisation or oversight of a constitutional mandate? Corrective rape of black African lesbians in South Africa' (2015) 15 African Human Rights Law Journal 58-88.
} 
in South Africa that is shaped by the country's history and closely connected to the many social, economic and political challenges facing it today. ${ }^{12}$

Undoubtedly, legacies of structural violence live on for black and poor South Africans, regardless of gender, working on the mines, farms and factories and for those living in impoverished rural areas or urban settlements and slums, often separated from families and communities. Lack of health services, adequate nutrition and reliance on dangerous transport continue to determine the length of a person's life based on their race and class. Service delivery protests, workplace violence starkly displayed in the Marikana massacre, xenophobic bloodshed, and everyday brutal crime shape the South African reality. While this violent backdrop gives context to, and perhaps partly explains, the levels of violence against women ${ }^{13}$ it does not diminish the enormity of this issue - it is neither dramatic nor imprecise to characterize this violence as a war against women. ${ }^{14}$

It is clear that while violence against women is prevalent across social classes, the combination of poverty shaped by race has a fundamental impact on women's vulnerability to violence (and related to this, also to HIV infection). Lack of access to income and employment deepens women's dependency on men and limits their capacity to leave violent partners. Limited access to housing and social security also make escape impossible for many. Inadequate health care and social services mean that responses to violence often fall short of what is needed. Poor basic services such as transport, sanitation, water and electricity expose women to risks of attack in urban and rural environments. Similarly, girls face daily dangers in walking to school, at school where toilets may be some distance from classrooms or absent entirely, and where predatory teachers often behave with impunity. Certain groups facing additional challenges, such as women with disabilities, lesbians, elderly women, and

\footnotetext{
12 This violent context is the product of the way in which masculinity and femininity is culturally defined and gender inequality is produced. It should be noted at the outset that gender-based violence also affects men and boys although women and girls are its major victims. This chapter chooses to use the term violence against women rather than more gender neutral terminology to keep the focus on the imbalance between men and women that reflects the underlying patriarchal roots of this violence..

${ }^{13}$ For a discussion of the causes of violence against women in South Africa today see, L. du Toit 'Shifting meanings of postconflict sexual violence in South Africa' (2014) 40(1) Signs 101-123.

${ }^{14}$ C. A. MacKinnon, Are Women Human? And Other International Dialogues (Cambridge, Massachusetts: Harvard University Press, 2006), has noted that: 'Men violently dominating other men for control of states is called war; men violently dominating women within states is relegated to peace': p. 5. But note the concerns with this approach to sexual violence and the state: R. Kapur, 'Gender, sovereignty and the rise of a sexual security regime in international law and postcolonial India' (2013) 14(2) Melbourne Journal of International Law 317-342.
} 
women refugees and migrants, have greater exposure to abuse because of their intersectional disadvantage. ${ }^{15}$

This challenging context raises questions about how the country should respond with the necessary urgency in marshalling the resources to end this war. It also raises questions about the role of the Constitution in informing the boundaries and shape of the law as part of such a response. While some feminist scholars are sceptical about rights and laws in tackling violence against women, others suggest that law should be one, albeit limited, part of the approach to this challenging issue. ${ }^{16}$ Law is seen by the latter as a contested arena that must be engaged with in the context of the broader project of ending sexual oppression and gendered power imbalances. Women's groups were central to efforts to include strong gender equality rights and protections against violence in the South African Constitution. This text has since been used to inform legislative development of rape and domestic violence laws and to defend and improve such laws through the courts. The Constitutional Court has been a focus of litigation on issues of violence against women and has produced sensitive and progressive jurisprudence in this area.

This chapter will briefly discuss the history and nature of the constitutional text as it pertains to violence against women (Part II) before looking, also briefly, at the key legislative developments in the areas of domestic violence and rape (Part III) over the past 20 years. Thereafter, it will survey the decisions of the Constitutional Court that dealt with this legislation as well as a series of decisions that dealt with the common law in cases where women were victims of male violence (Part IV). It will evaluate these decisions in terms of criteria set out in Part IV. The chapter will argue (Part V) that a fuller interpretation of the Constitution and more creative litigation and jurisprudence is necessary in addressing violence against women, in particular through the use of social and economic rights.

This chapter is a domestic rather than comparative evaluation of the South African constitutional project that assesses the Court's performance within South Africa's specific

\footnotetext{
${ }^{15}$ As noted at $\mathrm{n} .11$, gender-based violence affects other vulnerable groups such as boys and gay men.

${ }^{16}$ In the latter category, in the South African context see, C. Albertyn et al, 'Women's freedom and security of the person' in E. Bonthuys and C. Albertyn (eds.) Gender, Law and Justice (Cape Town: Juta, 2007) 295. In the US context see the foundational article by E. Schneider, 'The dialectic of rights and politics: perspectives from the women's movement' (1986) 61 New York University Law Review, 589-652. For a discussion of human rights as a contested space in responding to violence against women, see S. E. Merry, Human Rights and Gender Violence (Chicago: University of Chicago Press, 2006).
} 
historical and current context, and considers the unrealized opportunities that the constitutional text presents for those working to end violence against women. The chapter, nevertheless, provides insight for comparative scholars considering the value of different constitutional articulations of human rights and how these support (or fail to support) efforts to address violence against women. It also provides a view of the jurisprudential opportunities and pitfalls in this area that may be applicable elsewhere. Gender equality, and central to this, the right of women to live lives free of violence, is a precondition for full democratic participation ${ }^{17}$ and is a universal goal. ${ }^{18}$ The South African experience contributes to a wider understanding of the possibilities and limits of constitutions in challenging the ubiquity of violence against women.

\section{The Constitutional text}

The involvement of women as a lobby group in shaping the content of South Africa's new Constitution focused on ensuring that gender equality was strongly protected. ${ }^{19}$ There was no specific acknowledgement of rights for women facing violence in and outside of the home in the Interim Constitution 1993. However, with input from the women's lobby, ${ }^{20}$ feminist parliamentarians and technical experts involved in the drafting of the Final Constitution 1996 succeeded in including the words 'to be free from all forms of violence from either public or private sources $^{21}$ in s. 12 of the Bill of Rights which deals with freedom and security of the person as well as significant reproductive and sexual rights within the same section. These notable additions aligned with and were informed by international developments of the same period. In 1994, the United Nations General Assembly adopted the Declaration on the

\footnotetext{
${ }^{17}$ See, e.g., N. Fraser, Justice Interruptus: Critical Reflections on the "Postsocialist" Condition (New York: Routledge, 1997); M. Nussbaum, Women and Human Development: The Capabilities Approach (Cambridge: Cambridge University Press, 2000).

${ }^{18}$ United Nations, Sustainable Development Goals, Goal Five.

${ }^{19}$ C. Albertyn, 'Women and the transition to democracy in South Africa' (1994) Acta Juridica 39-63.

${ }^{20}$ C. Albertyn (ed.), Engendering the Political Agenda: A South African Case Study (Johannesburg: University of Witwatersrand, Centre for Applied Legal Studies, 1999), pp. 120-121, 66-68.

${ }^{21}$ Constitution of the Republic of South Africa 1996, s. 12(1)(c). The whole section reads as follows:

Section 12 Freedom and security of the person

(1)Everyone has the right to freedom and security of the person, which includes the right -

a. not to be deprived of freedom arbitrarily or without just cause;

b. not to be detained without trial;

c. to be free from all forms of violence from either public or private sources;

d. not to be tortured in any way; and

e. not to be treated or punished in a cruel, inhuman or degrading way.

(2) Everyone has the right to bodily and psychological integrity, which includes the right -

a. to make decisions concerning reproduction;

b. to security in and control over their body; and

c. not to be subjected to medical or scientific experiments without their informed consent.
} 
Elimination of Violence Against Women ${ }^{22}$ and in the same year the Cairo Programme of Action articulated women's reproductive rights at the International Conference on Population and Development. ${ }^{23}$ Both of these statements on women's rights reflected a shift towards recognising women's agency over their bodies and required the breaking down of some of the harmful public/private divisions in law that had rendered violence against women invisible. ${ }^{24}$ The international law has been specifically referenced by the Constitutional Court in some of the key decisions on violence against women. ${ }^{25}$

The inclusion of freedom and security and bodily integrity rights was part of a broader constitutional commitment to non-sexism ${ }^{26}$ as evidenced by the strong equality right which includes sex, gender, pregnancy and marital status as grounds of unfair discrimination. ${ }^{27}$ The anti-discrimination legislation, mandated by the Constitutional equality right, prohibits unfair discrimination based on gender which includes gender-based violence and female genital mutilation. ${ }^{28}$ The Act also prohibits harassment based on sex and gender ${ }^{29}$ and gender-related hate speech. ${ }^{30}$ Its preamble makes reference to patriarchy, alongside colonialism and apartheid, as systems that generated inequality and caused pain and suffering to the majority of South Africans. ${ }^{31}$ The Constitution also established a Commission for Gender Equality as an independent body to promote and protect gender equality. ${ }^{32}$ The Constitution contains a provision regarding the role of the police service in protecting the public. ${ }^{33}$

\footnotetext{
${ }^{22}$ UN GAOR $48^{\text {th }}$ sess., U.N. Doc. A/Res/48/104 (1994).

${ }^{23}$ A/CONF.171/13, Report of the International Conference on Population and Development: Cairo 5-13 September 1994 (94/10/18) (18 October 1994).

${ }^{24}$ E. Bonthuys and W. Domingo, 'Constitutional and international law context' in E. Bonthuys and C. Albertyn (eds.) Gender, Law and Justice (Cape Town: Juta, 2007) 51 pp. 64-8. For a discussion of South Africa's international human rights compliance see: M. Govender, 'Domestic violence: is South Africa meeting its obligations in terms of the Women's Convention?' (2003) 19 South African Journal on Human Rights 663-678. For a broader discussion of human rights as a response to violence against women see: R. Manjoo 'Violence against women as a barrier to the realisation of human rights and the effective exercise of citizenship' (2016) 112 Feminist Review 11-26.

${ }^{25}$ Bothma $v$ Els and Others (2010) 1 BCLR 1 (Constitutional Court), at para. 55-6; S v. Baloyi [2000] 1 BCLR 86 (Constitutional Court), at para. 13; Masiya v. Director of Public Prosecutions Pretoria (The State) and Another [2007] 8 BCLR 827, at para. 37; Carmichele v. Minister of Safety and Security [2001] 10 BCLR 995 (Constitutional Court), at para. 62 .

${ }^{26}$ Constitution of the Republic of South Africa 1996, preamble, s. 1(b).

${ }^{27}$ Ibid s. 9.

${ }^{28}$ Promotion of Equality and Prevention of Unfair Discrimination Act 2000, ss. 8(a)-(b).

${ }^{29}$ Ibid s. 1.

${ }^{30}$ Ibid s 2(c).

${ }^{31}$ Ibid preamble.

${ }^{32}$ Constitution of the Republic of South Africa 1996, s. 187.

${ }^{33}$ Ibid s. 205(3). This role is elaborated by O'Regan J in K v. Minister of Safety and Security [2005] 9 BCLR 835 (Constitutional Court), at para. 52.
} 


\section{Legislative developments}

It was this broad and hard-won constitutional framework that informed the development of new post-apartheid laws on violence against women. In the first decade of democracy, huge effort was expended in creating strong legislative measures to address and respond to violence against women. This resulted in the enactment of the Domestic Violence Act $^{34}$ to allow courts to provide protection orders and the Sexual Offences Act which expands the definitions of rape and other sexual offences. ${ }^{35}$ Both pieces of legislation were informed by the urgent need to address violence against women and by the constitutional promise of freedom and security.

The Domestic Violence Act replaced the Prevention of Family Violence Act ${ }^{36}$ which was hurried through in the last days of the Apartheid Government. The new Act was framed in terms of South Africa's constitutional commitments to freedom and security of the person and equality and its international obligations to end violence against women and children. The Act contains a broad and progressive definition of domestic violence that includes economic abuse, damage to property and controlling or abusive behaviour alongside more traditionally recognised forms such as physical abuse and sexual harassment. ${ }^{37}$ Complainants can obtain interim and final protection orders from courts that can include a wide range of conditions limiting the respondent's access to the home or workplace of the complainant and requiring the payment of rent and emergency relief. ${ }^{38}$ The protection order is accompanied by a warrant of arrest that can be used if the order is breached and criminal sanctions can be imposed on contravention of an order. ${ }^{39}$ Despite its positive features, the Domestic Violence Act has been criticised for its piecemeal approach (it neglects issues of child custody and matrimonial property) as well as for focusing on policing and the courts without also legislating in areas such as health care, housing and income support. ${ }^{40}$

The Sexual Offences Act was introduced after a lengthy consideration by the South African Law Reform Commission and an extended consultation process that took a decade to produce

\footnotetext{
${ }^{34}$ Domestic Violence Act 1998.

${ }^{35}$ Criminal Law (Sexual Offences and Related Matters) Amendment Act 2007.

${ }^{36}$ Prevention of Family Violence Act 1993.

${ }^{37}$ Domestic Violence Act 1998, s. 1.

38 Ibid s. 7.

${ }^{39}$ Ibid ss. 8, 17.

${ }^{40}$ Vetten, 'Deserving and undeserving women' (n. 8), p. 43.
} 
changes to the law. The Act aimed to bring the out-dated definition of rape and related offences in line with the rights in the Constitution. This led to changes in the definition that recognised rape could involve penetration into the vagina, anus or mouth of the victim with any body part or object. ${ }^{41}$ It also introduced gender neutrality into the definition of rape by recognising that anyone, men included, could be a victim of the crime. The Act expanded on sexual crimes against children and people with mental disabilities and introduced laws related to trafficking. The Act also provided some rights to victims for post exposure prophylaxis to avoid HIV infection and introduced a sexual offences register. While many feminists were actively involved in lobbying for the new legislation, some felt despondent about the eventual content of the law. Artz and Smythe, commenting shortly before the Sexual Offences Bill was enacted, argued that the focus on the constitutional right to equality rather than the right to be free from all forms of violence led to law with a 'peculiarly liberal feminist flavour' ${ }^{42}$ This is particularly evident in the gender neutral definition of rape, taken together with the lack of measures to protect victims, that has 'muted the distinctly gendered experience of sexual assault'. ${ }^{43}$ They suggested that the removal of gendered language has 'edited out the structural reality of gender-based violence' and the uneven gender power relations between men and women. ${ }^{44}$ Artz and Smythe were also critical of the failure to remove 'consent' from the definition of rape. They were particularly concerned with the relegation of measures to protect victims in the criminal justice system to the policy framework of government rather than being located within the Act, as originally intended. Their conclusion was that the reform of rape law has been somewhat symbolic but has had some value in terms of public education. However, huge challenges remain to shift practices within the justice system and the jurisprudence and to improve the experiences of victims.

Both Acts have been accompanied by various policy plans by government to give effect to these laws and develop wider responses. Dishearteningly, many commentators have bemoaned the poor implementation of these laws and plans in the period since their enactment. Dee Smythe has noted in relation to rape laws and policies that: ${ }^{45}$

\footnotetext{
${ }^{41}$ Criminal Law (Sexual Offences and Related Matters) Amendment Act 2007, s. 1 (definition of sexual penetration).

${ }^{42}$ L. Artz and D. Smythe, 'Feminism vs. the State? A decade of sexual offences law reform in South Africa' (2007) 74 Agenda 6-13 at 10.

${ }^{43}$ Ibid 11.

${ }^{44}$ Ibid.

${ }^{45}$ Smythe, Rape Unresolved (n. 5), at pp. 46-7.
} 
South Africa is paper rich when it comes to dealing with sexual violence. It has ratified the leading international and regional human rights treaties and instruments seeking to address these problems, and enshrined a constitutional protection against privately perpetrated violence, applied and enforced through decisions of our highest courts. At a policy level, the South African government and the police service have identified violence against women as a critical policing priority and enacted institutional safeguards against inappropriate responses to rape complainants through National Instructions and Standing Orders. The problem is not with the law in the books but with criminal justice practice. It is in the practical realities of everyday policing and in the attendant discretionary choices, that police responses to rape crumble, reinforcing the pretext that rape is, essentially, a crime that is impervious to policing.

There is less despondency about the implementation of the Domestic Violence Act but concerns remain about the training of government officials, access to justice for poor women as well as the lack of options for women fleeing violence. ${ }^{46}$ These two laws have been the subject of litigation in the Constitutional Court, in some cases leading to their improvement and in others defending their provisions. The next Part examines this jurisprudence as well as three decisions relating to the interpretation of the common law where the state failed to protect women from violent assault and rape.

\section{Constitutional court jurisprudence}

This Part evaluates the jurisprudence of the Constitutional Court over the past 20 years on the subject of violence against women. ${ }^{47}$ While the Supreme Court of Appeal and the provincial

\footnotetext{
${ }^{46} \mathrm{H}$. Combrinck 'The dark side of the rainbow: violence against women in South Africa after ten years of democracy' (2005) Acta Juridica 171-199; L. Artz and D. Smythe 'Bridges and barriers: a five year retrospective on the Domestic Violence Act' (2005) Acta Juridica, 200-226; Vetten, 'Deserving and undeserving women' (n. 8).

47 The following decisions, in chronological order, are considered here: $S$ v. Baloyi [2000] 1 BCLR 86

(Constitutional Court); Carmichele v. Minister of Safety and Security [2001] 10 BCLR 995 (Constitutional

Court); Ex Parte Omar [2003] 10 BCLR 1087 (Constitutional Court); K v. Minister of Safety and Security [2005] 9 BCLR 835 (Constitutional Court); Masiya v. Director of Public Prosecutions Pretoria (The State) and Another [2007] 8 BCLR 827; Director of Public Prosecutions, Transvaal v. Minister for Justice and Constitutional Development and Others [2009] 7 BCLR 637 (Constitutional Court); Bothma v Els and Others [2010] 1 BCLR 1 (Constitutional Court); F v. Minister of Safety and Security and Another [2012] 3 BCLR 244 (Constitutional Court); Teddy Bear Clinic for Abused Children and Another v. Minister of Justice and Constitutional Development and Another [2013] 12 BCLR 1429 (Constitutional Court) (Teddy Bear Clinic); J v. National Director of Public Prosecutions and Another [2014] 7 BCLR 764 (Constitutional Court). The case of $S$ v. Marais [2010] 12 BCLR 1223 (Constitutional Court), dealing with an appeal by a woman who arranged for her husband to be killed will not be included in the discussion. Her unsuccessful appeal concerned her wish
} 
High Courts have handed down some very important constitutional judgments on this subject, mostly dealing with criminal law and procedure, this broader jurisprudence will not be canvassed here. ${ }^{48}$ The Constitutional Court decisions are evaluated in terms of a number of criteria that, as discussed in the introductory chapter to this collection, combine both internal and external measures of success. This evaluation considers, first, whether the jurisprudence pursues the transformatory mandate inherent in the Constitution in ensuring laws aimed at achieving far-reaching social change including substantive gender equality. ${ }^{49}$ Second, and related to this, whether the Court's decisions infuse the interpretation of the law and the rights in the Bill of Rights of the Constitution with the democratic values underlying the Constitution of dignity, equality and freedom. ${ }^{50}$ Third, whether they effectively engage with and provide guidance on the legal responses to violence against women and advance the law in this area. Fourth, whether they provide a consistent, coherent and convincing jurisprudence on violence against women that fairly balances sometimes competing constitutional rights. These are narrow criteria, judged qualitatively, that do not attempt to evaluate the possible impact that the Constitution or the Court has had on governmental or public responses towards violence against women, let alone on the reduction of this violence. ${ }^{51}$

Before examining the Court's decisions it is worth noting the factual issues in nine of the leading judgments lest the real people involved become lost in the legal discussion. ${ }^{52}$ The following is a brief description, in chronological order, of the types of violence that led to the judgments under discussion.

\footnotetext{
to bring further evidence of her status as a battered women as a defence against her conviction and sentence. The Constitutional Court's decision is primarily procedural and the substantive issue of the battered woman defence had already been decided by the Supreme Court of Appeal in the case of $S$ v. Ferreira and Others [2004] 2 SACR 454 (SCA). The decisions in National Coalition for Gay and Lesbian Equality and Another v. Minister of Justice and Others [1998] 12 BCLR 1517 and Geldenhuys v. National Director of Public Prosecutions and Others [2009] 5 BCLR 435 (Constitutional Court), although concerning definitions of sexual offences, are not included here since they do not concern violence against women. Both cases, formal equality decisions, related to the unfairly discriminatory criminalization of male to male sexual conduct.

${ }^{48}$ For a discussion of some of these decisions see, Albertyn et al, 'Women's freedom' (n. 15); M. J. Maluleke and T. Madonsela, Gender Equality Jurisprudence in Landmark Court Decisions (Department of Justice and Constitutional Development, 2009).

${ }^{49}$ See, K. Klare, 'Legal culture and transformative constitutionalism' (1998) 14 South African Journal on Human Rights 146-188; C. Albertyn and Beth G., 'Facing the challenge of transformation: difficulties in the development of an Indigenous jurisprudence of equality' (1998) 14 South African Journal on Human Rights $248-276$.

${ }^{50}$ As set out in s. 39(1)(a) of the Constitution of the Republic of South Africa 1996 and informed by ss. 7(1) and $36(1)$.

${ }^{51}$ See the discussion of the evaluation of causation in the introductory chapter by Dixon and Roux.

${ }^{52}$ In the Teddy Bear Clinic case there were no individual applicants or respondents as the case was brought directly by organizations challenging the constitutionality of laws.
} 
The complainant in Baloyi's case alleged that her husband, an army officer, assaulted her and threatened to kill her following the granting of an interdict where he had been ordered not to assault her and their child or prevent them from leaving or entering their joint home. ${ }^{53}$ Alix Carmichele was brutally assaulted by Francois Coetzee who had previously been convicted of indecent assault of one woman, and attempted rape of a 17-year-old girl. He attacked Carmichele with a pick handle and stabbed her with a knife after breaking into the house where she was staying. In Omar's case, the applicant was arrested for breaching a domestic violence order in which he had been prohibited from 'threatening, assaulting, harassing, intimidating, stalking or abusing' his estranged wife and their children. In $K$ 's case a 20 -yearold woman was stranded without transport and was offered a lift by three policemen who then assaulted and took turns raping her. Masiya was accused of anal penetration of a nineyear-old girl. In DPP v Minister for Justice and Constitutional Development and others, Phaswane was convicted of the rape of a thirteen-year-old girl who was the sister of his cohabiting partner. In the same case, Mokoena was convicted of the rape of an eleven-yearold girl. Bothma's case concerned a woman who claimed she was repeatedly raped over two years from the age of thirteen by a much older family friend. In $F$ 's case, a thirteen-year-old girl was given a lift home by a policeman who assaulted and raped her. In the case of $J$, a fourteen-year-old boy was convicted of the rape of a seven-year-old boy and two six-year-old boys. He was also convicted of assault for stabbing a twelve-year-old girl.

The facts in the cases that have reached the Constitutional Court reflect the reality of vicious crimes against women, girls and boys. Most of the victims were female and many were children. Aside from age, other indicators of vulnerability include the lack of access to transport, women's fear for their safety on the streets, and poverty that forced a young girl and woman to seek lifts from policemen. A number of the victims were women and children who were unable to find safety from violence in their own homes. All of the perpetrators were male.

The Constitutional Court's ten decisions on violence against women broadly concern three areas: sexual offences and how the criminal law and procedure treat victims and perpetrators of sexual crimes; the constitutionality of domestic violence legislation; and the boundaries of

\footnotetext{
${ }^{53} \mathrm{He}$ alleged, although this was version was not accepted, that his wife and her brother had assaulted him.
} 
civil liability of the state where it fails to protect victims from physical and sexual harm by employees and other offenders.

\section{(a) Sexual offences}

The sexual offences judgments deal with one decision that arose before the coming into force of the Sexual Offences Act concerning the common law definition of rape; a decision concerning the time delay in the prosecution of child abuse; and three decisions arising from the reforms to the law after 2007.

Masiya's case concerned the common law definition of rape which excluded anal penetration and was gender specific. The case reached the Court shortly before the long awaited Sexual Offences Act created a statutory crime of rape 'applicable to all forms of sexual penetration without consent, irrespective of gender' ${ }^{54}$ It is an important judgment in setting out the patriarchal history of rape (in both its colonial and customary origins) that saw the crime in terms of the interests of male protectors of women rather than in terms of the rights of the women themselves; and understanding this history in terms of male dominance and power, objectification of women, and gender stereotyping. ${ }^{55}$ The judgment noted that the new Constitution provides a different foundation for the law of rape based on the democratic values of the Constitution of human dignity, equality and freedom. ${ }^{56}$ In particular, the rights to freedom from violence, equality and dignity are implicated in relation to this crime ${ }^{57}$ The Court acknowledged the role of women's activism in challenging patriarchal notions of rape and in ensuring the wide acceptance that 'sexual violence and rape not only offends the privacy and dignity of women but also reflects the unequal power relations between men and women in society'. ${ }^{58}$ This led the Court to extend the definition so as to "promote the spirit, purport and objects of the Bill of Rights' 59 and the 'principles, ideals and values underlying the Constitution' ${ }^{60}$

\footnotetext{
${ }^{54}$ Criminal Law (Sexual Offences and Related Matters) Amendment Act 2007, preamble. See ch. 2, pt. 1, s. 3 for the definition.

${ }^{55}$ Masiya v. Director of Public Prosecutions Pretoria (The State) and Another [2007] 8 BCLR 827, at para. 24.

${ }^{56}$ Ibid at para. 25.

${ }^{57}$ Ibid at para. 27.

${ }^{58}$ Ibid at para. 28.

${ }^{59} \mathrm{Ibid}$.

${ }^{60} \mathrm{Ibid}$ at para. 45 .
} 
The majority decision of Nkabinde $\mathbf{J}$ (followed by eight judges) did, however, refuse to extend the definition of rape to non-consensual intercourse between men because in terms of the facts of the case this matter was not before the Court. It hinted, however, that law reform was needed in this regard. ${ }^{61}$ This was disputed by Langa CJ in a minority decision (Sachs $\mathbf{J}$ concurring) where he found that the absence of men in the definition of the crime failed to give 'effect to the constitutional values of dignity, equality and freedom: dignity through recognition of a violation; equality through equal recognition of that violation; and freedom as rape negates not only dignity, but bodily autonomy'. ${ }^{62}$ While Nkabinde $\mathrm{J}$ highlighted the particular vulnerability of women and girls to rape, ${ }^{63}$ Langa CJ focused on the protection of all people, regardless of gender. ${ }^{64} \mathrm{He}$ stressed that this recognition would not detract from the understanding that women are the 'primary target of rape' and that 'male domination of women is an underlying cause of rape'. ${ }^{65} \mathrm{He}$ went further to argue that limiting rape as a crime against women might entrench stereotypes of women as vulnerable, hence reinforcing their subordinate position. ${ }^{66} \mathrm{He}$ argued that male rape is as much about 'gender-supremacy' as female rape and hence, from an equality perspective, requires equal protection. ${ }^{67}$ Langa $\mathrm{CJ}$ justified the development of the common law beyond the facts presented in the case on the basis that curing the gender defect in the law was a necessary part of the development of the crime of rape based on the underlying constitutional principles, as necessitated by the case before the Court. ${ }^{68}$

Langa CJ's decision is more deeply aligned with a substantive understanding of gender inequality since it recognises the concurrence of male and female gender-based harm while acknowledging the patriarchal underpinnings of and manifestation of the crime. Ultimately, it offers more transformatory possibilities than the minority decision in requiring gender equality to include more far-reaching and systemic cultural, social and psychological change if sexual violence is to be addressed. ${ }^{69}$ Commenting on this decision, Bonthuys argued that the majority incorrectly focussed on 'the sex of the victims and perpetrators, rather than on a

\footnotetext{
${ }^{61}$ Ibid at para. 31.

62 Ibid at para. 80.

${ }^{63}$ Ibid at para. 37.

${ }^{64}$ Ibid at para. 84.

65 Ibid.

${ }^{66}$ Ibid para. 85 .

${ }^{67}$ Ibid para. 86.

${ }^{68}$ Ibid para. 90.

${ }^{69}$ See also, C. Albertyn, 'Substantive equality and transformation in South Africa' (2007) 23 South African Journal on Human Rights 253-276.
} 
proper understanding of gender'. ${ }^{70}$ She suggested that the majority's approach in Masiya reflected a similarly conservative approach followed by the Court in the $\operatorname{Jordan}^{71}$ case where it failed to acknowledge that the criminalization of the sale of sex but not its purchase was unfair gender discrimination. ${ }^{72}$ The Court appeared to be favouring a safe and narrow approach to issues of sexuality where 'bad' women and male rape victims do not fit the image of the victim requiring protection. ${ }^{73}$ The Langa CJ judgment, in succinctly capturing the implications of rape as a violation of the core values of the Constitution, led to a more nuanced and progressive re-interpretation of the common law.

In Bothma's case the Constitutional Court balanced the accused's right to a fair trial against the interests of a complainant alleging child sexual abuse and society's need for justice. The High Court had permanently stayed a private prosecution by Mrs Bothma who alleged she had been raped as a child. It found that she had waited an unreasonable length of time (39 years) which prejudiced the right to a fair trial of the man she accused. The Constitutional Court granted Mrs Bothma's appeal against the High Court decision on the basis that victims of child sexual abuse can take many years to acknowledge, report, and pursue complaints. The Court referred to Nkabinde's strong statements on the crime of rape in the Masiya decision and added the context of unequal power arising from age differences that impact on the silencing of children who have been sexually abused. ${ }^{74}$ Sachs $\mathbf{J}$ found that: ${ }^{75}$

Without pronouncing on the veracity of her charges, it should be noted that there also exist strong public policy reasons for allowing the nature of the crime to weigh heavily in favour of allowing these charges to be aired in court. Adults who take advantage of their positions of authority over children to commit sexual depredations against them, should not be permitted to reinforce their sense of entitlement by overlaying it with a sense of impunity. On the contrary, the knowledge that one day the secret will out, acts as a major deterrent against sexual abuse of other similarly vulnerable children.

The decision is a further demonstration of the Court's contextual understanding and firm stance on sexual violence.

\footnotetext{
${ }^{70}$ E. Bonthuys, 'Putting gender into the definition of rape or taking it out? Masiya $v$ Director of Public Prosecutions (Pretoria) and Others, 2007 (8) BCLR 827 (CC)' (2008) 16 Feminist Legal Studies 249-260 at 254.

71 Jordan v. S [2002] 11 BCLR 1117 (Constitutional Court).

72 Bonthuys, 'Putting gender into the definition of rape' (n. 69), at 258.

${ }^{73}$ Ibid.

${ }^{74}$ At para. 47.

${ }^{75}$ At para. 66.
} 
The following cases came to the Court after the enactment of the Sexual Offences Act in 2007. This Teddy Bear Clinic case was an attempt to correct a defect in the new Act that was overly broad in restricting consensual sexual activity between adolescents leading to inappropriate and harmful criminalization of children. It was brought by not-for-profit organisations working with victims of child abuse. The applicants argued that the Act violated the rights of children to dignity, privacy and bodily integrity and was not in their best interests. $^{76}$ They argued that the provisions of the Act would unnecessarily expose children to the criminal justice system and would constrain 'healthy attitudes to sexual behaviour'. ${ }^{77}$ The position taken by the applicants was supported by two amici curiae representing women's interests who argued that girls would be disproportionately affected by the provisions and that the provisions resulted in indirect discrimination based on sex. ${ }^{78}$ Khampepe $\mathrm{J}$, in a unanimous decision, found that the provisions impaired the dignity of adolescents by leading to stigma and shame with potentially traumatic and harmful consequences. ${ }^{79}$ Dignity was closely linked to privacy and was also negatively impacted by the provisions. ${ }^{80}$ The provisions were not in the best interests of children who should not be held criminally responsible for consensual sexual behaviour. Criminalization would drive behaviours underground and prevent children from having open discussions with parents. ${ }^{81}$ The Court thus found the provisions to be invalid to the extent of their inconsistency but suspended this declaration for 18 months to allow Parliament to rework the statute. During this period of suspension, the Court ordered a moratorium on investigations, arrests and prosecutions of adolescents and to expunge any convictions or sentences under the Act and remove these from the sexual offences register. The Court refused to consider the additional contention of the applicants regarding the undesirable absence of a 'close in age' defence for 16 and 17 year olds who engage in sexual conduct with adolescents.

The decision, while not directly following an instance of violence against women, was important in addressing a problem with the newly enacted Sexual Offences Act. The Act had intruded too far into the realm of consensual sex in attempting to protect children from violence by criminalizing normal sexual activity between adolescents. The judgment, in

\footnotetext{
${ }^{76}$ Teddy Bear Clinic for Abused Children and Another v. Minister of Justice and Constitutional Development and Another [2013] 12 BCLR 1429 (Constitutional Court) para. 29 (Teddy Bear Clinic).

${ }^{77}$ Ibid para. 28.

${ }^{78}$ Ibid para. 36.

${ }^{79}$ Ibid paras. 52-8.

${ }^{80}$ Ibid paras. $59-64$.

${ }^{81}$ Ibid para 89.
} 
going against this somewhat conservative sentiment, was more realistic and enlightened with regard to sexual behaviour of adolescents. While it hinted that sex education was more appropriate than criminalization, ${ }^{82}$ it was careful not to prescribe any particular policy response to the State. ${ }^{83}$ The judgement is disappointing in failing to engage with the value of freedom or the right to freedom and security of the person. While it examined issues of privacy and dignity in relation to children with some sensitivity, it would have been beneficial if it had given greater consideration to the positive dimensions of the rights to bodily integrity and freedom and security of the person in line with the Constitutional values.

As with the Teddy Bear Clinic case, J's case related to the rights of children, in this case those of child offenders. Here, there was mandatory inclusion of children convicted of sex offences against children or persons with a mental disability on the National Register for Sex Offenders. ${ }^{84}$ The inclusion on the Register meant that listed people were precluded from working with, supervising or assuming caring responsibilities for children. The Constitutional Court found that the legislation resulted in serious violations of the best interests of children. In weighing up whether limitations of the rights of these children were justified, the Court acknowledged the competing rights of child offenders and other vulnerable groups to be safe from abuse. The Court stressed that: ${ }^{85}$

Sexual violence threatens a victim's rights to freedom and security of the person, privacy and dignity in a profound way. Sexual offences have effects that ripple far beyond the horrific immediacy and physicality of the crime. Our success or failure as a community to prevent and protect against sexual violence has bearing on us all, collectively and individually. (footnotes omitted)

Nevertheless, the Court decided that the limitation of the rights of child offenders was not justified as there were less restrictive means to achieve the purpose of the legislation. However, the Court was unable to craft an order that would remedy the situation without a broader re-examination of the Act as a whole. It therefore declared the section invalid but suspended the declaration of invalidity for 15 months to enable the legislature to remedy the defect. The Court was mindful of the fact that the Act was already being reconsidered

\footnotetext{
${ }^{82}$ Ibid para. 99.

${ }^{83}$ Ibid para. 100.

${ }^{84}$ In terms of s. 50(2) of the Criminal Law (Sexual Offences and Related Matters) Amendment Act 2007 (Sexual Offences Act).

${ }^{85}$ J v. National Director of Public Prosecutions and Another [2014] 7 BCLR 764, para. 48.
} 
following the Teddy Bear Clinic case. It also ordered, as an interim measure, that the government provide details of children listed in the Register to the Court to make available to organisations assisting offenders. The Court demonstrated flexibility and the capacity to provide creative responses in its order in this case, whilst avoiding stepping on the toes of the legislature.

In 2015 Parliament made the necessary amendments to the Sexual Offences Act in response to both the Teddy Bear Clinic case and J's case. ${ }^{86}$

The case of DPP v Minister of Justice involved a somewhat more hands-on response by the Constitutional Court. The case involved statutory provisions dealing with the protection of child complainants in sexual offences cases. The Court refused to set aside the impugned provisions but acknowledged concerns with the administration of justice in regard to child complainants in sexual offences cases (as supported by evidence from the amici in the matter). One of the concerns was the lack of appointment of intermediaries for child complainants. Another was the lack of specialist sexual offences courts and officers to prepare child witnesses. Only a small number of regional courts had facilities to permit the use of intermediaries and even in those courts equipment was often not working. Intermediaries were poorly trained and unable to perform their functions adequately. Similarly, interpreters or prosecutors, used because they were easier to obtain than intermediaries, were not equipped to deal with child witnesses. Very few prosecutors had received appropriate training for these types of cases and magistrates were also lacking in specific training. The Court found this state of affairs to be inconsistent with the statutory promise of intermediaries or the constitutional promise of the centrality of the child's best interest. ${ }^{87}$ The Court pointed to the vulnerability of child sexual offences complainants who are not parties to criminal proceedings but who do have constitutional rights that must be protected. The Court stressed, in relation to poor implementation of the new laws, that: ${ }^{88}$

Compliance with the Constitution requires not only that laws be enacted to give effect to the rights in the Constitution, but also requires that these laws be implemented. Failure to implement laws that protect constitutional rights is a violation of the Constitution.

\footnotetext{
86 Criminal Law (Sexual Offences and Related Matters) Amendment Act Amendment Act 2015.

${ }^{87}$ Director of Public Prosecutions, Transvaal v. Minister for Justice and Constitutional Development and Others [2009] 7 BCLR 637, para. 198.

${ }^{88}$ Ibid, at para. 201.
} 
The Court also noted that the relevant subsections of the Criminal Procedure Act envisaged that the state would 'commit the necessary resources' to achieve the objectives of the Act and the Constitution. In a supervisory order, the Court called for information as a first step in the supervisory process, requiring the Department of Justice to list, within 90 days, the number of intermediaries and facilities (CCTV, separate rooms for testimony, one-way mirrors) available and needed; and the steps being taken to meet these needs. The Court gave the DPP and the amici the opportunity to comment on the information provided by the Minister. It left open the possibility that further directions might be needed to ensure supervision of its orders.

In following this decision, the Department of Justice provided the information as ordered. The Court then directed the Department to provide a further report in response to the comments on their first report by the DPP and some of the amici. The second report was required to provide information on the huge shortage of intermediaries and the many postponements in child rape cases resulting from this; whether the Department was considering increasing the rate of pay for intermediaries to 'an appropriate professional' level; the extent of the problem of malfunctioning equipment and what steps were being taken to address this quickly. The Department provided this report and made further information available in $2012 .{ }^{89}$

A 2015 report by the Centre for Child Law, one of the amici in the DPP case, examined the extent to which the supervisory order was followed by the Department of Justice five years later and whether the situation had improved. ${ }^{90}$ The report found that while there had been a quantitative improvement in the provision of services this was not adequately or consistently documented so it was hard to evaluate this provision based on available evidence. It called for better and clearer data collection. From a qualitative perspective the report found some positive examples of good practice but a lack of consistency and variations in the available resources. It called for a 'set of norms and standards applicable to the provision of acceptable court services for child victims and witnesses'. ${ }^{91}$ In relation specifically to the provision of intermediaries, the report found greater use and availability of these service providers, but it

\footnotetext{
${ }^{89}$ Centre for Child Law, Making Room: Facilitating the Testimony of Child Witnesses and Victims (Pretoria: Pretoria University Law Press, 2015), pp. 5-6.

${ }^{90}$ Ibid.

${ }^{91}$ Ibid p. 70.
} 
recommended the need to revise salaries and move away from contract appointments to address the shortage of intermediaries. ${ }^{92}$

The decision is commendable in taking a firm stand on lack of implementation of statutory provisions protecting sexual offence complainants. The Court's use of its supervisory jurisdiction was necessary and important in a context where good legal frameworks were failing through poor administration. However, it appears that despite the Court's role implementation remains inadequate. This raises two possibilities: first, that the Court may have needed to pursue its remedies more expansively; and second, that lack of resources and state capacity may remain challenges that cannot be immediately or easily addressed. The latter point suggests the unwelcome possibility that despite a responsive Constitutional Court, certain problems may be immune to judicial intervention.

Overall, the five sexual offences cases decided by the Court led to improved substantive and procedural law and, to some extent, to better administration of justice.

\section{(b) Domestic violence}

In two cases concerning domestic violence, one brought under the old legislation and the other under the newer Domestic Violence Act, the Court was strong in its defence of laws under attack from men named in court orders.

The case of $S \vee$ Baloyi concerned the predecessor to the Domestic Violence Act 1998, the Prevention of Family Violence Act 1993. It related to whether a provision requiring a person charged with breaching a family violence interdict to prove that they were not guilty violated their right to be presumed innocent. Sachs $\mathrm{J}$, in a unanimous judgment, found that the provision did not introduce a reverse onus and did not violate the rights of the person charged with breaching an interdict. The decision is significant in presenting a sophisticated argument, informed by feminist theory, for viewing domestic violence laws as different from other criminal law in the balancing of the rights of women to be safe from domestic violence

\footnotetext{
${ }^{92}$ Ibid pp. 64-65.
} 
against the rights of men accused of such crimes. In interpreting the s. 12 right to be 'free from all forms of violence from either public or private sources', Sachs J noted that: ${ }^{93}$

The specific inclusion of private sources emphasises that serious threats to security of the person arise from private sources. Read with section 7(2), section 12(1) has to be understood as obliging the state directly to protect the right of everyone to be free from private or domestic violence. Indeed, the state is under a series of constitutional mandates which include the obligation to deal with domestic violence: to protect both the rights of everyone to enjoy freedom and security of the person and to bodily and psychological integrity, and the right to have their dignity respected and protected, as well as the defensive rights of everyone not to be subjected to torture in any way and not to be treated or punished in a cruel, inhuman or degrading way. (footnotes omitted)

The right to be free from violence has thus been interpreted by the Court as placing a positive obligation on the state to protect women from domestic violence. ${ }^{94}$ The right is read together with s. 7(2) of the Constitution which requires the state to 'respect, protect, promote and fulfil the rights in the Bill of Rights'. Sachs J alluded to the distinction in the wording of s. 12 where the overall rights to freedom and security of the person (s. 12(1)) and to bodily and psychological integrity (s. 12(2)) are seen as essential features of personhood to which everyone is entitled to receive protection. Most of the sub-sections of ss. 12(1) and (2) contain the types of harms that people should not be subjected to - what Sachs $\mathrm{J}$ calls 'defensive rights'. Thus, people must expect the state to defend them against such harms while protecting their freedom, security and integrity.

Interestingly, Sachs $\mathbf{J}$ added the issue of dignity here to his discussion of the right. It is unclear whether he was referring to dignity as one of the three central values of the Bill of Rights set out in s. 7(1) of the Constitution or dignity as a right articulated in s. 10, or both. It seems curious to single out the value of dignity from the list of dignity, equality and freedom when freedom is so obviously central to the right in s. 12. Sachs J did, however, go on to consider equality when he argued that domestic violence 'compels constitutional concern' because it is 'gender-specific' and a product of a patriarchal society. ${ }^{95}$ This, he noted, meant that 'the non-sexist society promised in the foundational clauses of the Constitution, and the

\footnotetext{
${ }^{93} S$ v. Baloyi [2000] 1 BCLR 86 (Constitutional Court), at para. 11.

${ }^{94}$ As discussed in Albertyn et al, 'Women's freedom' (n. 15) p. 322.

${ }^{95} S$ v. Baloyi [2000] 1 BCLR 86, at paras. 11-12.
} 
right to equality and non-discrimination guaranteed by section 9, are undermined when spouse-batterers enjoy impunity'. ${ }^{96}$

Sachs $\mathrm{J}$ came to the issue of freedom when considering what autonomy means for women facing domestic violence. Drawing on feminist legal theory he noted that both autonomy and privacy have been used to shield men and prevent intervention to protect women in the home. He thus praised the idea behind domestic violence protection laws which are aimed at addressing the complexities of intimate partner abuse without immediate recourse to the criminal law. Sachs J pointed to the laudable purpose of protection legislation which 'at its most optimistic ... seeks preventive rather than retributive justice, undertaken with a view ultimately to promoting restorative justice'. ${ }^{97}$ The judgment has been rightfully lauded for its sensitive but firm elaboration of women's rights to be protected from domestic violence by the state.

Unlike Baloyi the Omar case was brought in terms of the newer Domestic Violence Act of 1998. It concerned a similar issue of the constitutionality of the provision of the Act that allowed a Court, when issuing a protection order, to authorize a warrant of arrest that would be suspended unless there was a breach of the protection order. ${ }^{98}$ The Court stated that: ${ }^{99}$

The high incidence of domestic violence in our society is utterly unacceptable. It causes severe psychological and social damage. There is clearly a need for an adequate legal response to it. Whereas women, men and children can be victims of domestic violence, the gendered nature and effects of violence and abuse as it mostly occurs in the family, and the unequal power relations implicit therein, are obvious. As disempowered and vulnerable members of our society, women and children are most often the victims of domestic violence.

The Court stressed that domestic violence 'brutally offends the values and rights' of the Constitution. ${ }^{100}$ Because of the 'complex public ... (and private) character' of domestic violence, measures were needed that differed from the general criminal laws. ${ }^{101}$ The Court examined the workings of the legislation and Omar's arguments that his rights of access to

\footnotetext{
${ }^{96}$ Ibid at para. 12.

${ }^{97}$ Ibid at para. 17.

${ }^{98}$ Domestic Violence Act 1998, s. 8.

${ }^{99}$ Ex Parte Omar [2003] 10 BCLR 1087 (Constitutional Court), at para. 13.

${ }^{100}$ Ibid at para. 17.

${ }^{101}$ Ibid at para. 18.
} 
court and to a fair trial and against arbitrary arrest were affected negatively. It found that none of these rights were compromised by the scheme of the Act and, as with Baloyi's case, there was no issue of a reverse onus. ${ }^{102}$ Since the Court found that none of the rights of a respondent in a domestic violence matter were infringed by the Act, it did not need to undertake any kind of balancing exercise. The Omar case did not significantly deepen the interpretation of the Constitutional framework on domestic violence as developed in Baloyi. It did, however, confirm the value and integrity of the Domestic Violence Act as a necessary and appropriate means of protecting women and children (primarily) from harm in the home.

Both decisions use the Constitution to defend women's rights to freedom and security and affirm the state's obligations to protect them. They do not, of course, consider how the Constitution might oblige the state to take measures to prevent violence against women from arising in the first place or to protect women by ensuring that they have access to the resources needed to avoid the violence that emerges in situations where poverty and disadvantage leave them defenceless.

\section{(c) State liability under the common law}

While the above cases deal with the state's obligations to protect women from violence in the home, the Court has given a series of decisions regarding the state's obligations to protect women from violent men outside of the home under the common law. The three cases of Carmichele (2001), $K$ (2005) and $F$ (2012) concern the way in which the Constitution informs the interpretation and development of the common law in situations where the state fails to protect people from criminal acts. In all three cases, the criminal acts concerned violent attacks on women and girls. These cases have proved highly significant, not just to the law of delict, but more generally to the understanding of the role of the Constitution in reshaping the common law. The Carmichele case dealt with the question of whether the state was liable for the conduct of police and prosecutors that led to a member of the public being harmed by a criminal who should not have been released on bail. It raised the question, of importance to this discussion, of the nature of the state's obligations to protect women from harm. The $K$ and $F$ cases were more narrowly focused on the vicarious liability of the state for victims of violent acts against women by policemen.

\footnotetext{
102 The Court declined to consider whether the definition of economic abuse in the Act was constitutionally valid.
} 
In a unanimous decision in Carmichele, the Constitutional Court stressed that the courts have an obligation to develop the common law having regard to the 'spirit, purport and objects of the Bill of Rights'. ${ }^{103}$ In determining whether police officers were under a legal duty to act, the Court said that the weighing up of the interests of the parties and the community involved a proportionality exercise that would need to be considered in the context of a 'constitutional state founded on dignity, equality and freedom and in which the government has positive duties to promote and uphold such values' ${ }^{104}$ This could entail both a duty not to perform an act that violates rights and a positive duty to provide protection. ${ }^{105}$ This echoes the comments of Sachs $\mathrm{J}$ in Baloyi regarding the state's obligations to protect people from domestic violence and promote their rights to freedom and security. ${ }^{106}$ The Constitutional Court found that the values underlying the Constitution pointed to the possible extension of liability to the state since the state, under the Constitution, has obligations to 'respect, protect, promote and fulfil the rights', 'and in particular, the right of women to have their safety and security protected'. ${ }^{107}$ It further noted that for police approaching their positive obligations arising from legislation and the Constitution, in relation to the rights to dignity and freedom and security of the person, 'few things can be more important to women than freedom from the threat of sexual violence'. ${ }^{108}$

The Court upheld Carmichele's appeal and referred the matter back to the trial court to conclude the trial and determine the factual and legal issues. The trial court found the Minister of Safety and Security was liable and this was confirmed by the Supreme Court of Appeal, ${ }^{109}$ effectively reversing the finding of the same court in an earlier hearing of the case. In the intervening period the test for wrongfulness in delict had been developed in light of the Constitution in the cases of Van Eeden ${ }^{110}$ which concerned an escaped repeat rapist and Van Duivenboden ${ }^{111}$ which concerned a man who killed his wife and child and shot a neighbour where he should not have been allowed to possess firearms.

\footnotetext{
${ }^{103}$ As stated in the Constitution of the Republic of South Africa 1996, s. 39(2); Carmichele v. Minister of Safety and Security [2001] 10 BCLR 995 (Constitutional Court) at paras. 38-39.

${ }^{104}$ Carmichele at para. 43.

105 Ibid at para. 26.

106 Baloyi at para. 11.

${ }^{107}$ Ibid at para. 57.

${ }^{108}$ Ibid at para. 62.

${ }^{109}$ Minister of Safety and Security v. Carmichele [2004] 2 BCLR 133 (Supreme Court of Appeal).

${ }^{110}$ Van Eeden v. Minister of Safety and Security [2002] 4 All SA 346 (Supreme Court of Appeal).

${ }^{111}$ Minister of Safety and Security v. Van Duivenboden [2002] 6 SA 431 (Supreme Court of Appeal).
} 
The Carmichele decision of the Constitutional Court has been broadly applauded for its focus on the centrality of the values and rights within the Constitution in shaping the development of the common law. In comparing the case with a similar case in the US courts, Roederer noted: ${ }^{112}$

\begin{abstract}
The contrast is between a court that views its constitution as a progressive covenant between the people and its government, which fosters a culture of justification and accountability, and a court that views its constitution as a charter of negative liberties, which will go to great lengths to conserve the status quo distribution of rights and entitlements. One is intent on protecting the vulnerable members of its society, and the other is skeptical of attempts by the legislature to do so through the creation of new rights. (footnotes omitted)
\end{abstract}

Commenting on the later case of $K$, Roederer argued that it showed, like Carmichele, a similar value-based response to state accountability and the obligation to protect vulnerable members of society. $K$ 's case concerned the nature and scope of vicarious liability in the situation where three policemen, while on duty, raped a young woman to whom they had offered a lift home. O'Regan $\mathrm{J}$, in a unanimous decision overturning the decision of the Supreme Court of Appeal, found the Minister of Safety and Security liable. The judgment developed the vicarious liability rule in line with the 'spirit, purport and objects of the Bill of Rights', following the Carmichele requirement that the normative values of the Constitution must inform the development of the common law. ${ }^{113}$ The court recognised that the principle of vicarious liability poses difficulties where the delictual act deviates from an employee's normal duties, and is even more difficult where it is an intentional wrong. ${ }^{114}$ The Court explained that the test for vicarious liability ${ }^{115}$ involves a subjective question of whether the wrongful acts were done purely for the benefit of the employee. Even where they were, there is still a further objective test of the sufficient closeness of the link between the employee's acts to further his or her own interests and the 'purpose and business of the employer'. ${ }^{116}$ This part of the test is both factual and legal - the legal component of sufficient closeness requires examination in terms of the 'spirit, purport and objects of the Bill of Rights'. ${ }^{117}$ In applying the redeveloped test to the facts of $K$ 's case the Court found that the policemen, in committing

\footnotetext{
${ }^{112}$ C. J. Roederer, 'The constitutionally inspired approaches to police accountability for violence against women in the U.S. and South Africa: conservation versus transformation' (2005) 13 Tulsa Journal of Comparative and International Law 91-140 at 93.

${ }^{113} \mathrm{~K}$ at para. 15.

${ }^{114}$ Ibid at para. 25.

${ }^{115}$ As set out in Minister of Police v. Rabie [1986] 1 SA 117 (A).

${ }^{116} \mathrm{~K}$ at para. 32.

${ }^{117} \mathrm{Ibid}$ at paras. 32, 44.
} 
the rape against $\mathrm{K}$, 'were simultaneously omitting to perform their duties as policemen'.118 O'Regan $\mathrm{J}$ noted that by offering $\mathrm{K}$ a lift, the policemen had induced her to trust them, something she was entitled to expect from the police in terms of the Constitution. They failed to meet their general duty to protect $\mathrm{K}$ from harm and their special duty in the particular situation of the case. 'The close connection between the wrongful conduct of the policemen and the nature of their employment' led to the Minister of Police being liable for K's damages. ${ }^{119}$ The policemen infringed K's constitutional rights to dignity and security of the person.

The decision sent a strong message to the governing bodies of the police that police personnel who abuse their positions of power remain the responsibility of the force. In a country where women live in fear of sexual violence, it is critical that they must be able to both expect protection from the police and feel confident that the police themselves will not abuse their authority and take criminal advantage of women.

The final and most recent case in the sequence of cases dealing with the common law in relation to liability following violent crimes against women is the case of $F$. Here, a 13-yearold girl was raped and assaulted by a policeman on standby duty who had given her a lift home. The case reached the Constitutional Court on appeal from the Supreme Court of Appeal (SCA) which had decided not to hold the Minister of Safety and Security liable. The majority decision of the SCA distinguished this case from $K$ 's case on the basis that a policeman on standby duty was not on duty and hence had not committed a delictual omission. It (mis)understood $K$ 's case to mean that an intentional commission such as rape could not result in vicarious liability for the state.

The Constitutional Court (Mogoeng J) considered the boundaries of the test for vicarious liability as set out in $K$ in the situation where a policeman on standby duty 'deviates from his employer's constitutional obligation to protect the public and engages in conduct that constitutes "the single greatest threat to the self-determination of South African women",

\footnotetext{
${ }^{118}$ Ibid at para. 48 (emphasis added).

${ }^{119}$ Ibid at para. 57.
} 
namely rape'. ${ }^{120}$ The Court followed the $K$ approach to determining vicarious liability in examining the facts of $F^{\prime}$ s case. It looked at the following factors: ${ }^{121}$

the state's constitutional obligations to protect the public; the trust that the public is entitled to place in the police; the significance, if any, of the policeman having been off duty and on standby duty; the role of the simultaneous act of the policeman's commission of rape and omission to protect the victim; and the existence or otherwise of an intimate link between the policeman's conduct and his employment.

Mogoeng $\mathbf{J}$ noted that rape by men of women and girls which is common and ongoing, and often goes unpunished, is a violation of a range of women and children's rights. ${ }^{122} \mathrm{He}$ went on to say that: ${ }^{123}$

The threat of sexual violence to women is indeed as pernicious as sexual violence itself. It is said to go to the very core of the subordination of women in society. It entrenches patriarchy as it imperils the freedom and self-determination of women. It is deeply sad and unacceptable that few of our women or girls dare to venture into public spaces alone, especially when it is dark and deserted. If official crime statistics are anything to go by, incidents of sexual violence against women occur with alarming regularity. This is so despite the fact that our Constitution, national legislation, formations of civil society and communities across our country have all set their faces firmly against this horrendous invasion and indignity imposed on our women and girl-children.

Mogoeng $\mathrm{J}$ stressed that courts must accept that common law rules are now subject to constitutional values and it is their duty to ensure that the fundamental rights of women and girl-children in particular are not made hollow by actual or threatened sexual violence'. ${ }^{24}$

The Court found that the standby duty status of the policeman did not preclude the state from liability as the focus of vicarious liability, following $K$ 's case, was the trust placed by the member of the public in the police. It also found that the SCA has misinterpreted the decision in $K$ that vicarious liability related not just to omissions of employees but commissions as

\footnotetext{
${ }^{120}$ K v. Minister of Safety and Security [2005] 9 BCLR 835 (Constitutional Court) para. 37. The Court was quoting counsel for the Centre for Applied Legal Studies, as cited in Carmichele at para. 62.

${ }^{121}$ Ibid at para. 52

${ }^{122}$ Ibid at para. 55

${ }^{123}$ Ibid at para. 56

${ }^{124}$ Ibid at para. 57
} 
well. It explained that rape by a policeman and his failure to protect the woman are 'two sides of the same coin' and are 'inseparable'. ${ }^{125}$ The Court accepted that the 'closeness of the connection' between the wrongful conduct of the policeman and his employment was more tenuous on the facts of this case than in $K$ 's but that the link was still sufficient to find the state vicariously liable.

The three cases clarify and extend the obligations of the state under the common law of delict to compensate women who have been harmed by violent men due to the inaction and action of state officials, particularly police and prosecutors. It remains to be seen whether the common law will be developed further, in light of the Constitution, in requiring state responsibility for the protection of women from public and private sources of violence. Dee Smythe notes that the 'full ambit of state obligations to protect, investigate, punish and compensate victims of sexual violence has not been fully explored in South African courts'126 and that 'the cases have dealt with harm suffered consequent to a failure by the police to comply with their obligations, rather than the harm intrinsic in such a failure.' ${ }^{127}$ This leads to a consideration of the way in which the Constitution might be used to greater effect in tackling violence against women in the ways that Smythe mentions and in ways that might create the conditions for violence to be reduced and prevented.

\section{Expanding constitutional opportunities to address violence against women}

An evaluation of the jurisprudence indicates that the Constitutional Court sees violence against women as an extremely serious infringement of human rights that is at odds with the values that underlie the Constitution. The Court has shown a willingness to develop the common law and require the improvement of statutes where these are failing to appropriately tackle this urgent social crisis. The Court has made it clear that the state has obligations in terms of the Constitution and international law to protect women from violence. The cases also point to the Court's preparedness to use its remedial jurisdiction to order remedies that require the state to expend resources and take actions to meet its obligations under the law. Most of the decisions are contextual in approach and situate legal development within an understanding of the extent, nature and impact of violence against women. This ensures that

\footnotetext{
${ }^{125}$ Ibid at para. 72.

${ }^{126}$ Smythe, Rape Unresolved (n. 5) at p. 30.

${ }^{127}$ Ibid p. 224, endnote 117.
} 
the decisions avoid conservative, inappropriate or formalistic approaches to law. The combination of a progressive Court and a strong constitutional text has resulted in jurisprudence and a constitutional model worth emulating elsewhere. ${ }^{128}$

The judgments discussed demonstrate an engagement with the rights to freedom and security of the person alongside dignity and equality as key rights contravened by acts of violence against women and children. The values of human dignity, equality and freedom have been given prominence in some of the leadings decisions set out above. Compared to some of the gender equality jurisprudence that has attracted criticism by feminist scholars, ${ }^{129}$ the violence against women jurisprudence is broadly progressive. However, the ten decisions in the 20 years of the Constitution have dealt only with the protection of women from harm and their treatment within the legal system or in claiming damages once such harm has occurred. No case dealing with the obligations of the state to take active measures to prevent violence against women has reached the Court, and this leads to a jurisprudential gap that should be remedied. It is a concern that a limited range of cases has reached the Court and that there has been a lack of opportunity for the Court to deepen its jurisprudence and provide far-reaching responses. Advocacy and service organizations representing violence victims have thus far played a mostly responsive role in assisting the Court (with the exception of the parties who brought the challenge to the provisions criminalizing under-age sexual conduct). ${ }^{130}$ There appear to be opportunities for such groups to creatively formulate new public interest litigation that engages the Constitution and the courts more effectively. The lack of litigation may reflect a number of things, including despondency within the sector about the value of good judgments when implementation remains so poor. Aside from looking to the Constitution for opportunities to litigate further in this area, the Constitution should be used as a framing document for new policy and law reform initiatives by the sector.

The South African constitutional experience on violence against women reflects some important successes but these must be taken further to expand the legal frameworks and the

\footnotetext{
${ }^{128}$ Note however, that although s. 12 was path breaking in referring to public and private violence, constitutional provisions on violence against women could be even more explicit and expansive, for example, The Constitution of the Tunisian Republic 2014, Art. 46, which says: 'The state shall take all necessary measures in order to eradicate violence against women'.

${ }^{129}$ E. Bonthuys, 'Institutional openness and resistance to feminist arguments: the example of the South African Constitutional Court' (2008) 20 Canadian Journal of Women and the Law 1-36; C. Albertyn, 'Law, Gender and Inequality in South Africa' (2011) 39 Oxford Development Studies 139-162.

${ }^{130}$ The Teddy Bear Clinic for Abused Children and RAPCAN in the Teddy Bear Clinic case.
} 
state's obligations in this area. There are real questions about the ability of the Court to address lack of state capacity in implementing its laws in the face of massive social and economic problems, including the epidemic of violence against women. Clearly, the Constitution alone is not sufficient to solve this issue. Nevertheless, it is a text with the capacity to contribute further, in tandem with a range of other mechanisms and actors to tackle this major challenge.

This last part of the chapter considers some of the constitutional possibilities that could be explored to expand the Constitution's reach in both protecting women from violence and responding to it. These include: developing the meaning and content of the right to freedom and security of the person in s. 12; deepening the interpretation of the constitutional values and considering their substantive content; drawing on the social and economic rights, in combination with s. 12 and the right to equality to obtain the necessary resources and action by the state in addressing violence that is closely tied to gendered poverty. Other rights such as rights to culture and religion may also prove important in challenging practices that lead to violence and abuse of women.

\section{Developing the interpretation of s. 12}

The right to freedom and security of the person in s. 12 of the Constitution is capable of further interpretation and elaboration by the courts. The positive and negative dimensions of the right could be more fully spelt out as a basis for expanding the boundaries of state obligations to address violence against women. The various dimensions of the right have implications for women facing violence. Thus, deprivation of freedom referred to in s. 12(1)(a) may result from controlling partners or parents who prevent women and girls from working, socialising or participating in their communities, using physical, psychological, economic and other forms of control. The idea of freedom from violence from public or private sources referred to in s 12(1)(c) may involve some definition with regard to acts of abuse by teachers, religious leaders or employers. In the employment context, sexual harassment is sanctioned but this does not necessarily mean that employers are taking active steps to prevent its occurrence. In situations where people face job insecurity, common in high unemployment contexts such as South Africa, the right might need to be used to require measures to prevent harassment and abuse of women workers. Similarly, in the schooling context where power inequalities, together with poverty, shape girls' capacity to challenge teachers who abuse them, the right should be used to expand the available preventative and 
responsive measures. Sadly, the references in s. 12 to torture and cruel, inhuman and degrading treatment are relevant to women in South Africa where rape, domestic violence and other forms of abuse can be categorised in these terms. Strong statements by the court on these definitional overlaps would be important in clarifying the conceptual boundaries of violence against women as a violation of human rights. ${ }^{131}$ Similarly, bodily and psychological integrity, the second part of s. 12, has important meaning in the context of violence against women, particularly the sub-right of 'security in and control over their body'. In a country where many young people of both sexes believe that non-consensual sex is normal, ${ }^{132}$ fulfilling the s. 12 right might entail educational programmes to address these alarming perceptions. ${ }^{133}$ Marius Pieterse discusses the possibilities of using s. 12 to obtain material outcomes in the health sphere and points to judicial decisions in South Africa and Canada that might support this interpretation. Similar arguments could be applied in the area of violence against women. ${ }^{134}$

\section{Deepening the substantive interpretation and application of the constitutional values}

The values of dignity, equality and freedom underlying the rights in the Bill of Rights require ongoing interpretation and development in the context of the particular rights they inform and the circumstances of the cases reaching courts. In considering the development of the right to equality in its engagement with culture, Albertyn has proposed an interpretation of the fundamental constitutional values as follows: ${ }^{135}$

dignity as affirming the humanity of each person and their entitlement to equal concern and respect; equality as remedying of disadvantage and enabling redistribution (difference should not be a basis for disadvantage); an affirmation of difference and diversity (positive differences should be recognised and developed); and freedom as autonomy, participation and the establishment and nurturing of conditions for substantive choice.

\footnotetext{
${ }^{131}$ On the relationship between violence against women and human rights, see Manjoo, 'Violence against women', (n. 23).

${ }^{132}$ R. Jewkes and N. Abrahams, 'The epidemiology of rape and sexual coercion in South Africa: an overview' (2002) 55 Social Science and Medicine 1231-1244.

${ }^{133}$ For recommendations of the types of programs to address these attitudes see E. Fulu et al, Why Do Some Men Use Violence Against Women and How Can We Prevent It? Quantitative Findings from the United Nations Multi-Country Study on Men and Violence in Asia and the Pacific. (UNDP, UNFPA, UN Women and UNV, 2013).

${ }^{134}$ M. Pieterse, 'The interdependence of rights to health and autonomy in South Africa' (2008) 125 South African Law Journal 553-572. See also, D. Bhana, 'The substance of contractual autonomy in the twenty-first century: the South African experience’ (2015) 48(4) VRÜ Verfassung in Recht und Übersee, 491-515.

${ }^{135}$ C. Albertyn, 'The stubborn persistence of patriarchy'? Gender equality and cultural diversity in South Africa' (2009) 2 Constitutional Court Review 165-208 at 187.
} 
She notes that freedom is the least developed constitutional value and, like Pieterse, argues for a substantive conception of freedom that enables choice, agency and participation. Violence is multi-dimensional in its impact on women, limiting their opportunities, life choices, access to resources and to full participation in society. Understanding dignity, freedom and equality substantively involves addressing these various dimensions of the impact of violence on women. The development of substantive freedom as a fundamental value underlying all rights in the context of violence against women is a critical conceptual constitutional project that may lead to practical outcomes for victims. For example, if sex workers who face regular sexual violence are not provided with the mechanisms to resist attack because the employment 'choices' they make are frowned upon, then freedom is given a meaning that is narrow and unresponsive. ${ }^{136}$

\section{Drawing on the social and economic rights (together with other rights)}

Scholars examining the Constitutional Court's jurisprudence on violence against women have pointed to the need to look to the social and economic rights in the Constitution to address the conditions of poverty that expose women to violence and limit their access to appropriate services. ${ }^{137}$ A study by Elsje Bonthuys has considered the issue of domestic violence in particular and the ways in which social and economic rights might be used to overcome the implementation deficiencies of the Domestic Violence Act. ${ }^{138}$ This is innovative research both within South Africa and beyond where the links between violence against women and social and economic rights have not been fully theorised in constitutional or international human rights law. Conceptually, Bonthuys brings together the right to gender equality and socioeconomic rights to focus on the issue of domestic violence against women specifically. She draws on work that has combined substantive gender equality with socio-economic rights to address the conditions of material disadvantage and status-based discrimination that adversely affect women. ${ }^{139}$

\footnotetext{
${ }^{136}$ See research on the relationship between freedom, access to property and resources, and domestic violence in the Indian context: B. Aggarwal and P. Panda, 'Toward freedom from domestic violence: the neglected obvious' (2007) 8 Journal of Human Development 359-388.

${ }^{137} \mathrm{P}$. Andrews, 'Learning to love after learning to harm: post-conflict reconstruction, gender equality and cultural values' (2007) 15 Michigan State Journal of International Law 41-62 at 62; Combrinck, 'The dark side of the rainbow' (n. 45) at 196-8.

${ }^{138}$ E. Bonthuys, 'Domestic violence and gendered socio-economic rights: an agenda for research and activism' (2014) 30 South African Journal on Human Rights 111-133.

${ }^{139}$ S. Fredman, 'Engendering social and economic rights' in B. Goldblatt and K. McLean (eds.) Women's Social and Economic Rights - Developments in South Africa, (Cape Town: Juta, 2011) p. 4. This involves an
} 
While Bonthuys' argument provides a fruitful framing of the issues and the basis for further research, litigation and advocacy on domestic violence it leaves certain conceptual and substantive questions open for further development. At a conceptual level, the reliance on gender equality, together with socio-economic rights, to provide the substantive responses to domestic violence against women overlooks the need to theorize the relationship between the right to freedom and security of the person and socio-economic rights. The rights in s. 12 need to be given substantive content based on a rich conception of the value of freedom that requires state and private provision of the means to exist as free and autonomous members of society. At a substantive level, Bonthuys' paper only addressed domestic violence and there would be value in a similar study that considers the role of social and economic rights in addressing other forms of sexual or gender-based violence. Such a study might lead to ideas for creative litigation including the installation of lighting in informal settlements to make streets safer for women, education programmes in school to address male and female attitudes to sex, transport for girls to reach school safely or, as required by the Bombay High Court, the provision of women's toilets in public places that has a positive impact on their safety. ${ }^{140}$ Private provision of services and supports might also be required in terms of social and economic rights, for instance, to address violence against women and sexual harassment in the workplace.

We know there are problems with state capacity and implementation and that solving these problems takes time. Constitutional rights can create the enabling framework for communitybased responses that are less resource-dependent than orders requiring state provision of services. An example of this might be a program undertaken by school students, parents and teachers to ensure girl students are accompanied to school by protective groups based on a roster system. Creative local responses can be defended by courts where they face regulatory challenges or can be rolled out to other areas by courts. Such strategies should not, however,

\footnotetext{
application of Fredman's focus on both distributive and status-based features of equality, to violence against women. Fredman's conception of four-dimensional substantive equality includes these recognition and redistribution dimensions but also requires a focus on participation and transformative approaches. It would be valuable to map all of Fredman's equality dimensions of socio-economic rights as a response to violence against women. It would also be important to think about intersectional discrimination and how violence against women has different implications for a variety of different groups such as women with disabilities, lesbians, and women in religious communities.

${ }^{140}$ Milun Saryajani v. Pune Municipal Corporation and Others, P. I. L. No. 98 of 2011, H. C. Bom, (23

December 2015).
} 
be seen as transferring state obligations to women and communities, themselves time and resource poor. ${ }^{141}$

\section{Conclusion}

This chapter, in examining the jurisprudence of the Constitutional Court on violence against women over the past 20 years, has noted the valuable framework created by the Court in defining the state's obligations in this area. It has argued that this framework requires expansion if it is to offer additional space for attempts to use law to challenge systemic and ongoing violence. The chapter has made some suggestions for ways in which this jurisprudential framework might be developed and where creative litigation might bring new issues into focus for the Court. These areas of development would be aided by considering comparative and international jurisprudence and might also impact on debates in these terrains. It is clear that it is a difficult economic and political context in which to demand more from a state whose capacity to implement existing laws and policies is limited. But it is always a difficult time for women facing violence or its threat on a daily basis. It is necessary to use all available measures to end the war against South Africa's women and the Constitution remains one of the important tools for this task.

\footnotetext{
${ }^{141}$ For a discussion of some of the dangers of placing obligations on poor women to address social problems that should be fixed by the society as a whole, see S. Chant, "The "feminisation of poverty" and the "feminisation” of anti-poverty programmes: room for revision?' (2008) 44 Journal of Development Studies 165197; M. Molyneux, 'Mothers at the service of the new poverty agenda: progresa/oportunidades, Mexico's conditional transfer programme' (2006) 40 Social Policy \& Administration 425-449.
} 